ISSN: 2302-8556

E-Jurnal Akuntansi Universitas Udayana

Vol.25.3.Desember (2018): 2041- 2071

DOI: https://doi.org/10.24843/EJA.2018.v25.i03.p16

\title{
Lingkungan dan Disiplin Kerja Memoderasi Pengaruh Kompetensi Terhadap Kinerja Auditor
}

\author{
N. Diah Utami ${ }^{1}$ \\ A.A.N.B. Dwirandra ${ }^{2}$
}

\author{
${ }^{1}$ Fakultas Ekonomi dan Bisnis Universitas Udayana (Unud), Bali, Indonesia \\ email: diahutami02@gmail.com/Telp: 081967453827 \\ ${ }^{2}$ Fakultas Ekonomi dan Bisnis Universitas Udayana (Unud), Bali, Indonesia
}

\begin{abstract}
ABSTRAK
Lingkungan dan disiplin kerja mampu mempengaruhi kompetensi kinerja auditor dalam melaksanakan pemeriksaan audit. Kompetensi akan meningkatkan kinerja auditor apabila lingkungan sekitar mampu mendukung dalam melaksanakan tugasnya. Begitu juga dengan disiplin mampu meningkatkan kompetensi yang akan mempengaruhi kinerja auditornya. Penelitian ini dimaksud untuk mengetahui moderasi lingkungan dan disiplin kerja pada kompetensi auditor. Penelitian ini dilakukan di Kantor Inspektorat Kota Denpasar. Jumlah responden yang digunakan sebanyak 40 orang auditoryang dipilih menggunakan teknik purposive sampling dengan kriteria responden yaitu Kantor Inspektorat Kota Denpasar yang bersedia menerima kuisioner dan menjadi responden. Metode pengumpulan data dilakukan dengan metode survei menggunakan kuesioner. Teknik analisis data yang digunakan adalah Moderated Regresion Analysis (MRA). Hasil penelitian menyatakan bahwa variabel kompetensi berpengaruh padakinerja auditor, variable lingkungan kerja memoderasi pengaruh kompetensi pada kinerja auditor, variabel disiplin kerja mampu memoderasi pengaruh kompetensi pada kinerja auditor.

Kata kunci: pengaruhkompetensi, lingkungan kerja, disiplin kerja, kinerja auditor.
\end{abstract}

\begin{abstract}
Environment and job discipline can influence the competence of auditor's performance in carrying out audit examination. Competence will improve the performance of auditors if the surrounding environment is able to support in carrying out its duties. This research was conducted at Inspectorate Office of Denpasar City. The number of respondents used as many as 40 auditors selected using purposive sampling technique with the criteria of respondents namely the Office of Inspectorate of Denpasar who are willing to accept the questionnaire and become respondents. Methods of data collection were conducted by survey method using questionnaire. Data analysis technique used is Moderated Regresion Analysis (MRA). The result of the research stated that the competence variable has an effect on the performance of the auditor, the job environment variables to moderate the influence of competence on the auditor's performance, the job discipline variable can moderate the influence of competence on the auditor's performance.
\end{abstract}

Keywords: influence of competence, job environment, job discipline, auditor performance 


\section{PENDAHULUAN}

Auditing adalah pengumpulan dan evaluasi bukti tentang informasi untuk menentukan dan melaporkan derajat kesesuaian antara informasi itu dan kriteria yang telah ditetapkan (Meylinda dan Budiartha, 2015). Tujuan akhir dari proses auditing ini adalah menghasilkan laporan audit, laporan audit inilah yang digunakan oleh auditor untuk menyampaikan pernyataan atau pendapatnya kepada pemakai laporan keuangan (Nila, 2014). Laporan keuangan merupakan media umum bagi pihak internal untuk mempertanggungjawabkan pengelola sumber daya perusahaan kepada pihak eksternal. Pemenuhan standar audit oleh auditor dapat berdampak pada peningkatan hasil auditnya, yaitu dengan hasil kinerja yang maksimal (Riris dan Lenny, 2016).

Menurut SPAP PSA No.02 SA Seksi 110 (SPAP, 2011) menyatakan bahwa “tujuan audit atas laporan keuangan oleh auditor independen pada umumnya adalah untuk menyatakan pendapat tentang kewajaran, dalam semua hal yang material, posisi keuangan, hasil usaha, perubahan ekuitas, dan arus kas sesuai dengan Standar Akuntansi Keuangan di Indonesia. Peran auditor merupakan profesi kepercayaan yang diberikan masyarakat untuk mutu jasa auditor (Alnoprika,2015).

Istilah kinerja digunakan untuk menyebutkan prestasi atau tingkat keberhasilan individu atau kelompok individu (Lismawati, 2014). Kinerja yang baik tentunya tidak terbentuk begitu saja, namun ditentukan oleh banyak faktor. Menurut satwika dan ramantha (2015) mengemukakan kinerja auditor merupakan aktivitas penilaian independent yang dibentuk dalam rangka menguji dan mengawasi kegiatan- 
ISSN: 2302-8556

E-Jurnal Akuntansi Universitas Udayana

Vol.25.3.Desember (2018): 2041- 2071

kegiatan perusahaan yang bertujuan membantu anggota perusahaan agar dapat menyelesaikan tanggungjawab untuk merencanakan dan melaksanakan audit agar memperoleh keyakinan memadai bahwa manajemen menjalankan operasional perusahaan dengan baik dan memenuhi kriteria yang telah ditetapkan dan mendeteksi penipuan atau kecurangan dan memelihara pengendalian perusahaan (Rita et al., 2011).

Kinerja Auditor diharapkan mampu melaksanakan tugasnya sebagaimana mestinya dalam waktu yang sudah ditentukan. Hal ini ditunjukan untuk menjamin bahwa pelaksanaan kegiatan tersebut telah sesuai dengan kebijakan rencana yang telah disepakati sebelumnya agar dalam pencapaian tersebut sesuai dengan keinginan dan kebutuhan terhadap kebijakanperaturan dan hukum yang berlaku (Azza dan Zhou, 2010). Peran auditor telah menjadi pusat kajian dari riset di kalangan akademis. Kinerja adalah hasil kerja secara kualitas dan kuantitas yang dicapai oleh seorang pegawai dalam melaksanakan tugasnya sesuai dengan tanggung jawab yang diberikan kepadanya (Mangkunegara, 2006).

Salah satu faktor yang dapat mempengaruhi kinerja auditor adalah kompetensi. Menurut pamungkas (2012) menyatakan bahwa kompetensi berpengaruh signifikan terhadap kualitas kinerja audit. Hal ini menunjukkan dengan tingkat kemampuan yang dimiliki oleh auditor akan menunjang kualitas kinerja audit yang dihasilkan.

Undang-undang Republik Indonesia No. 13/2003 tentang Ketenagakerjaan menyebutkan bahwa kompetensi kerja adalah kemampuan setiap individu yang 
mencakup aspek pengetahuan, keterampilan, dan sikap kerja yang sesuai dengan standar yang ditetapkan. Hal itu menunjukan bahwa kompetensi mencakup tugas, keterampilan, sikap dan apresiasi yang harus dimiliki oleh pegawai dan pimpinan untuk dapat melaksanakan tugas-tugas pembelajaran sesuai dengan jenis pekerjaan tertentu. Organisasi akan berkembang dan mampu bertahan dalam lingkungan persaingan yang kompetetif apabila didukung oleh pegawai-pegawai yang berkompetensi di bidangnya. Kompetensi dapat digunakan untuk memprediksi kinerja yaitu siapa yang berkinerja baik dan kurang baik tergantung kompetensi yang dimilikinya, diukur dari kriteria atau standar yang digunakan (Linawati dan Suhaji, 2012).

Kompetensi auditor adalah kualifikasi yang dibutuhkan oleh auditor untuk melaksanakan audit dengan benar (Ayuningtyas dkk, 2012). Menurut Brown, et al (2007) auditor akan dapat menyelesaikan auditnya secara efektif jika didukung kemampuan, karena dengan kemampuan maka auditor dapat mendeteksi kesalahan yang akan berimbas pada kinerja yang semakin membaik. Sehingga dapat dikatakan ketika auditor memiliki kompetensi dan kualifikasi yang baik, maka pemahaman yang dimiliki atas suatu laporan keuangan juga akan lebih baik sehingga auditor dengan cepat akan dapat menganalisis kesalahan yang terjadi.

Hasil penelitian sebelumnyaoleh Indah (2010) menyatakan bahwa kompetensi berpengaruh signifikan terhadap kinerja auditor, dimana kompetensi merupakan salah satu indikator dalam menilai kinerja auditor. Penelitian Dermawan Dkk (2011) dan Ariani (2015) juga membuktikan bahwa kompetensi berpengaruh signifikan terhadap 
ISSN: 2302-8556

kinerja auditor.Berbeda dengan penelitian Linawati dan Suhaji (2012) kompetensi tidak berpengaruh signifikan terhadap kinerja auditor.Begitu juga dengan Zamroni (2015) yang mengatakan bahwa kompetensi tidak berpengaruh signifikan terhadap kinerja auditor.Terlihat terdapat ketidakkonsistenan hasil antara penelitian-penelitian yang telah dilakukan sebelumnya. Menurut Govindarajan (1986), untuk mengatasi ketidakkonsistenan hasil-hasil penelitian sebelumnya, maka diperlukan pendekatan kontingensi (contingency approach).

Pendekatan kontijensi memungkinkan adanya variabel-variabel lain yang dapat bertindak sebagai pemoderasi yang memengaruhi hubungan antara lingkungan dan disiplin kerja (Wijayanthi, 2016). Faktor-faktor kontingensi tersebut terdiri dari beberapa faktor, seperti ketidakpastian lingkungan, faktor individu, maupun manajerial dalam konteks organisasi secara keseluruhan (Ajibolade dan Akinniyi, 2013). Ketidakkonsistenan hasil antara penelitian-penelitian sebelumnya menjadi motivasi peneliti untuk melakukan penelitian kembali mengenai pengaruh kompetensi pada kinerja auditor. Selain itu, peneliti juga menggunakan variabel lingkungan dan disiplin kerja sebagai variabel pemoderasi yang mungkin akan memperkuat atau memperlemah pengaruh kompetensi pada kinerja auditor.

Lingkungan kerja adalah kehidupan sosial, psikologi, dan fisik dalam perusahaan yang berpengaruh terhadap pekerja dalam melaksanakan tugasnya. Kehidupan manusia tidak terlepas dari berbagai keadaan lingkungan sekitarnya, antara manusia dan lingkungan terdapat hubungan yang sangat erat. Lingkungan kerja yang kondusif meliputi penetapan jam kerja, peraturan yang berlaku, serta lingkungan 
fisik. Lingkungan ini sangat penting terutama bagi keselamatan dan kenyamanan karyawan dalam menjalankan tugasnya. Dalam hal ini, manusia akan selalu berusaha untuk beradaptasi dengan berbagai keadaan lingkungan sekitarnya. Demikian pula halnya ketika melakukan pekerjaan, karyawan sebagai manusia tidak dapat dipisahkan dari berbagai keadaan disekitar tempat mereka bekerja, yaitu lingkungan kerja. Selama melakukan pekerjaan, setiap pegawai akan berinteraksi dengan berbagai kondisi yang terdapat dalam lingkungan kerja.

Lingkungan kerja sangat berperan penting dalam pengaruh kualitas kerja auditor. Tidak hanya itu, praktisi juga semakin kritis dengan menganalisa kontribusi. Kualitas kinerja harus ditingkatkan baik dari segi pendidikan, pengalaman mengaudit, komitmen atas pekerjaannya dan disiplinya dalam bekerja agar mampu mempercepat penyelesaian laporan audit sesuai kontrak dan menghasilkan kualitas audit yang baik (Wicaksana, 2015).Dalam upaya meningkatkan kinerja agar lebih baik sangat perlu adanya lingkungan yang mendukung. Lingkungan yang menyenangkan dapat memberikan kepuasan karyawan dalam bekerja serta memiliki kepuasan serta rasa aman yang dapat mempengaruhi peningkatan kinerja karyawan, karena karyawan tidak merasa terganggu dalam melaksanakan tugas-tugasnya (Supriyatno, 2007).

Disiplin kerja merupakan salah satu aspek yang berhubungan dengan kinerja auditor. Zesbendri dan Aryanti (2005), menyebutkan bahwa disiplin merupakan modal utama yang mempengaruhi tingkat kinerja karyawan. Menurut Ardana, dkk (2011), disiplin kerja merupakan suatu sikap menghormati, menghargai, patuh dan taat terhadap peraturan-peraturan yang berlaku, baik yang tertulis maupun yang tidak 
ISSN: 2302-8556

tertulis serta sanggup menjalankan dan tidak mengelak untuk menerima sanksisanksinya.

Auditor yang memiliki disiplin kerja yang tinggi dapat meningkatkan kinerja yang selanjutnya bisa meningkatkan kualitas audit yang akan dihasilkan. Menurut Rivai (2004), disiplin kerja adalah suatu alat untuk merubah sikap seseorang agar mentaati dan menghormati peraturan-peraturan yang berlaku. Auditor juga harus membudayakan disiplin kerja agar dapat mendukung pencapaian tujuan organisasi. Hal ini akan mencerminkan dari kepatuhan seorang karyawan terhadap peraturan kerja dan juga sebagai tanggungjawab terhadap perusahaan (Bimantara, 2013).

Disiplin sangat penting digunakan arahan untuk membentuk dan melatih seseorang melakukan sesuatu menjadi baik. Disiplin juga merupakan proses untuk menumbuhkan perasaan seseorang dalam mempertahankan dan meningkatkan tujuan dalam berorganisasi secara objektif melalui kepatuhannya menjalani peraturan organisasi. Disiplin kerja dalam berorganisasi akan secara langsung mempengaruhi moral pegawai maupun pelayanan yang diberikan.

Peranan tersebut tidak terlepas dari upaya positif yang dapat dilakukan dalam mendapatkan sebagai wujud dari pencpaian tujuan utama suatu organisasi. Dalam hal ini, kedisiplinan penting bagi organisasi sebab nantinya akan ditaati oleh sebagian karyawan dan diharapkan dapat membuat pekerjaan dilakukan dengan efektif. Disiplin lebih diterapkan dan lebih ditekankan pada unsur kesadaran individu untuk mengikuti peraturan-peraturan yang berlaku dalam organisasi (Susilaningsih, 2008). 
Pada audit pendekatan kontijensi juga diperlukan agar auditor mengetahui karakteristik klien yang akan di audit. setelah itu aduit juga diharapkan menyusun dan menyesuaikan strategi audit yang tepat untuk digunakan dalam penugasan audit. Strategi audit ini bertujuan sebagai proses penyusunan arahan atau petunjuk audit dan penyelarasan antara pemahaman auditor dan penugasan degan focus audit yang akan dilakukan. Auditor harus bias mempertimbangkan kegiatan utama dan indicator kinerja untuk industry asejenis yang dapat berpengaruh terhadap proses audit. auditor juga harus mengidentifikasikan factor-fakto penting bagi keberhasilan pelaksanaan audit, baik dalam menyusun program audit untuk merumuskan opini audit maupun dalam menyediakan jasa pelayanan professional bermutu lainnya.

Auditor tidak dapat melaksanakan tanggung jawabnya sebagai auditor, bertindak dengan meletakkan keamanan di atas semua faktor yang dikaitkan dengan kerja, sehingga ketika mendapat tekanan maupun menghadapi tugas yang kompleks maka ia akan cenderung mencari jalan yang aman dan bahkan berperilaku disfungsional dalam membuat judgment. Sedangkan auditor yang dapat bertanggung jawab atas tugasnya dan tetap bersikap profesional dalam menjalankan tugas sebagai auditor, tidak akan terpengaruh meskipun ia mendapat tekanan dan menghadapi tugas audit yang kompleks, sehingga dapat membuat judgment yang lebih baik dan tepat (Praditaningrum 2012).

Audit merupakan suatu proses pemeriksaan yang dilakukan secara sistematis dan kritis oleh pihak independen terhadap laporan keuangan yang telah disusun oleh manajemen beserta catatan-catatan pembukuan dan memberikan pendapat mengenai 
ISSN: 2302-8556

kewajaran terhadap laporan keuangan (Agoes, 2004). A Statement of Basic Auditing Concepts (ASOBAC) mendefinisikan auditing sebagai suatu proses sistematis untuk menghimpun dan mengevaluasi bukti-bukti secara objektif mengenai asersi-asersi tentang berbagai tindakan dan kejadian ekonomi untuk menentukan tingkat kesesuaian antara asersiasersi tersebutdengan kriteria yang telah ditentukan dan menyampaikan hasilnya kepada para pemakai yang berkepentingan (Halim,2015:1). Mulyadi (2002) menyatakan bahwa audit merupakan proses pemeriksaan secara objektif atas laporan keuangn suatu organisasi dengan tujuan untuk menentukan apakah laporan keuangan telah disajikan secara wajar, dalam semua hal yang material, posisi keuangan dan hasil usaha perusahaan atau organisasi tersebut.

Audit adalah suatu proses sistematis untuk memperoleh serta mengevaluasi bukti secara objektif mengenai asersi-asersi kegiatan dan peristiwa ekonomi, dengan tujuan menetapkan derajat kesesuaian antara asersi-asersi tersebut dengan kriteria yang telah ditetapkan sebelumnya serta penyampaian hasil-hasilnya kepada pihak yang berkepentingan (Boynton, 2006). Menurut Arens dkk (2011:4) audit adalah pengumpulan data dan evaluasi bukti tentang informasi untuk menentukan dan melaporkan derajat kesesuaian antara informasi itu dan kriteria yang telah ditetapkan. Audit harus dilakukan oleh orang yang kompeten dan independen.

Lingkungan kerja merupakan keadaan sekitar tempat kerja baik secara fisik maupun non fisik yang dapat memberikan kesan menyenangkan, mengamankan, menentramkan. Kondisi lingkungan kerja yang baik akan membuat pegawai merasa nyaman dalam bekerja. Kesan yang nyaman akan lingkungan kerja di mana karyawan 
tersebut bekerja akan mengurangi rasa kejenuhan dan kebosanan dalam bekerja. Kenyamanan tersebut tentunya akan berdampak pada peningkatan kinerja pegawai. Sebaliknya, ketidaknyamanan dari lingkungan kerja yang dialami oleh pegawai bisa berakibat fatal yaitu menurunnya kinerja dari pegawai itu sendiri.

Lingkungan kerja secara umum merupakan lingkungan dimana pekerja melaksanakan tugas pekerjaannya, dan terdiri dari lingkungan fisik dan non fisik. Lingkungan kerja fisik meliputi: pengelolaan gedung atau tata ruang kerja, penerangan, temperature, kebersihan, kebisingan suara, kerindangan halaman, warna dinding, kelengkapan kerja atau fasilitas kerja, keamanan dan kenyamanan, dan lain sebagainya yang dapat dilihat secara fisik. Sedangkan lingkungan kerja non fisik adalah meliputi: suasana kerja, hubungan dengan sesama karyawan, hubungan dengan pemimpin, organisasi karyawan (koperasi) dan pelayanan kepada masyarakat.

Robbins (2008) menyatakanlingkungan kerja atau lokasi kerja adalah segala sesuatu yang ada di sekitar para pekerjadan yang dapat mempengaruhi dalam menjalankan tugas-tugas yang dibebankan. Lingkungan kerja merupakan sesuatu yang ada disekitar para pekerja/karyawan yang dapat mempengaruhi kepuasan kerja karywan dalam melaksanakan pekerjaannya sehingga akan diperoleh hasil kerja yang maksimal, dimana dalam lingkungan kerja tersebut terdapat fasilitas kerja yang mendukung karyawan dalam penyelesaian tugas yang bebankan kepada karyawan guna meningkatkan kerja karyawan dalam suatu perusahaan.

Pengertian disiplin menurut Amran (2009) menjelaskan bahwa disiplin adalah sikap kesediaan dan kerelaan seseorang untuk mematuhi dan menaati segala norma 
ISSN: 2302-8556

peraturan yang berlaku di sekitarnya. Sedangkan menurut Zesbendri (2005) merupakan modal utama yang amat menentukan terhadap tingkat kinerja karyawan. Karyawan yang tingkat disiplinnya tinggi, maka kinerja akan baik, sedangkan karyawan yang tingkat disiplinnya rendah, maka kinerja akan rendah pula.

Terdapat banyak faktor-faktor yang mempengaruhi tingkat kedisiplinan karyawan suatu organisasi. Hasibuan (2000) menyebutkan faktor-faktor yang mempengaruhi tingkat kedisiplinan karyawan, yaitu tujuan dan kemampuan, teladan pimpinan, balas jasa, keadilan, waskat, sanksi hukuman, ketegasan, dan hubungan kemanusiaan.

Ariyanto dan Ardani (2010) mengatakan auditor sebagai ujung tombak dari fungsi pemeriksaan harus memiliki tingkat kemampuan, keahlian pengalaman yang dicerminkan dari kompetensi. Brown, et al (2007) mengatakan seorang auditor akan dapat menyelesaikan auditnya secara efektif jika didukung kemampuannya, karena dengan kemampuanya maka seorang auditor akan dapat mendeteksi kesalahan yang terjadi.

Kinerja dibedakan menjadi dua, yaitu kinerja individual dan kinerja organisasi. Menurut Engko (2006), kinerja individual mengacu pada prestasi kerja individu yang diatur berdasarkan standar atau kriteria yang telah ditetapkan oleh suatu organisasi. Kinerja individual yang tinggi dapat meningkatkan kinerja organisasi secara keseluruhan.

Kinerja (performance) adalah gambaran mengenai tingkat pencapaian pelaksanaan suatu kegiatan/program/kebijaan dalam mewujudkan sasaran, tujuan, 
misi dan visi organisasi yang tertuang dalam strategic planning suatu organisasi. Istilah kinerja sering digunakan untuk menyebut prestasi atau tingkat keberhasilan individu maupun kelompok individu (Husam et al., 2013). Sedangkan menurut Robbins (2008), kinerja merupakan hasil evaluasi terhadap pekerjaan yang dilakukan individu dibandingkan dengan kriteria yang telah ditetapkan bersama, pengertian kinerja sebagai hasil kerja secara kualitas dan kuantitas yang dicapai individu dalam melaksanakan tugasnya sesuai dengan tanggungjawab yang diberikan.

Menurut Bastian (2001), memberikan definisi kerja sebagai gambaran mengenai tingkat pencapaian pelaksanaan suatu kegiatan/program/kebijaksanaan dalam mewujudkan sasaran, tujuan, misi dan visi organisasi yang tertuang dalam perumusan skema strategis (strategic planning) suatu organisasi. Kinerja juga didefinisikian sebagai proses dimana organisasi mengevaluasi atau menilai prestasi kerja karyawan (Handoko, 2006:121). Kinerja merupakan pelaksanaan tugas pemeriksaan yang telah diselesaikan oleh auditor dalam kurun waktu tertentu.

Kompetensi auditor adalah kualifikasi yang dibutuhkan oleh auditor untuk melaksanakan audit dengan benar (Ayuningtyas dkk, 2012). Auditor harus memiliki pengetahuan untuk memahami objek pemeriksaan yang diaudit, kemudian auditor harus memiliki kemampuan untuk bekerja sama dalam tim serta kemampuan dalam menganalisa permasalahan. Tubbs (1992) berhasil menunjukkan bahwa semakin tinggi pengalaman dan pengetahuan seorang auditor mereka akan semakin peka dengan kesalahan penyajian laporan keuangan dan semakin memahami hal-hal yang terkait dengan keselahan yang ditemukan tersebut. Hal senada juga dinyatakan oleh 
ISSN: 2302-8556

Brown, et al (2007) auditor akan dapat menyelesaikan auditnya secara efektif jika didukung kemampuan, karena dengan kemampuan maka auditor dapat mendeteksi kesalahan yang akan berimbas pada kinerja yang semakin membaik. Sehingga dapat dikatakan ketika auditor memiliki kompetensi dan kualifikasi yang baik, maka pemahaman yang dimiliki atas suatu laporan keuangan juga akan lebih baik sehingga auditor dengan cepat akan dapat menganalisis kesalahan yang terjadi. Dengan memiliki kompetensi atau keahlian dalam jasa profesionalnya, maka akan mempengaruhi laporan hasil pemeriksaan yang merupakan salah satu penilaian terhadap kinerja auditor. Menurut penelitian Indah (2010) menyatakan bahwa kompetensi auditor berpengaruh positif terhadap kinerja auditor. Hal ini juga didukung oleh Yadnya (2017) yang menunjukan bahwa kompetensi berpengaruh positif.Hal ini berarti kinerja auditor dapat dicapai dengan memiliki kompetensi yang baik.

$\mathrm{H}_{1}$ : Kompetensi berpengaruh positif pada kinerja auditor.

Menurut Sedarmayanti (2011) menyatakan bahwa lingkungan kerja adalah keseluruhan alat perkakas dan bahan yang dihadapi lingkungan sekitarnya di mana seseorang bekerja, metode kerjanya, serta pengaturan kerjanya baik sebagai perseorangan maupun sebagai kelompok. Sedangkan menurut Menurut Nitisemito (2012) lingkungan kerja adalah segala sesuatu yang ada di sekitar para pekerja dan yangdapat memengaruhi dirinya dalam menjalankan tugas-tugas yang dibebankan, misalnya kebersihan, pencahayaan, dan sebagainya. Dalam menjalankan prosedur ini tentunya lingkungan kerja sangat berpengaruh dalam kompetensi yang dimiliki 
seorang auditor. Hasil penelitian olehJayaweera (2015) dan Iskandar (2017) menunjukan bahwa lingkungan kinerja berpengaruh signifikan terhadap kinerja auditor.

$\mathrm{H}_{2}$ : Lingkungan kerja mampu memoderasi pengaruh kompetensi pada kinerja auditor.

Disiplin menunjukan suatu kondisi atau sikap yang ada pada diri pegawai terhadap peraturan dan ketetapan organisasi. Dengan demikian bila peraturan atau ketetapan yang ada dalam organisasi diabaikan, atau sering dilanggar, maka pegawai mempunyai disiplin yang buruk. Sebaliknya, bila pegawai tunduk pada ketetapan, menggambarkan adanya kondisi disiplin yang baik. Disiplin juga sangat mempengaruhi kompetensi seorang auditor dalam melaksanakan tugasnya. Disiplin kerja harus dimiliki setiap karyawan dan harus dibudayakan di lingkungan sekitar karena sangat berpengaruh terhadap kompetensi yang sudah dimiliki. Menurut Zebendri dan Ariyanti (2005) menunjukan bahwa disiplin kerja berpengaruh signifikan terhadap kinerja auditor.

$\mathrm{H}_{3}$ : disiplin kerja mampu memoderasi pengaruh kompetensi pada kinerja auditor.

Variabel dependen/terikat dalam penelitian ini adalah kinerja auditor (Y).Variabel bebas dalam penelitian ini adalah kompetensi kerja (X1). Variabel moderasi dalam penelitian ini adalah lingkungan kerja (X2) dan disiplin kerja (X3). Populasi dalam penelitian ini adalah jumlah auditor yang ada di Kantor Inspektorat Kota Denpasar. Teknik pengambilan sampel dalam penelitian ini adalah purposive sampling. Purposive sampling merupakan teknik pengambilan sampel dengan menggunakan kriteria tertentu. Metode pengumpulan data yang digunakan adalah 
ISSN: 2302-8556

metode survei dengan instrumen kuesioner, yaitu dengan cara memberikan serangkaian pertanyaan atau pernyataan tertulis kepada responden untuk dijawab (Sugiyono, 2016). Kuesioner yang disebarkan berupa daftar pernyataan tertulis kepada responden mengenai kinerja auditor, lingkungan, disiplin dan kompetensi kerja.Teknik analisis dalam penelitian ini adalah Moderated Regression Analysis (MRA). Analisis data dalam penelitian ini dilakukan dengan bantuan program SPSS 21.0 for windows.

Model analisis data dan uji hipotesis dalam penelitian ini adalah model analisis regresi moderasi MRA (Moderated Regression Analysis). Pengujian ini bertujuan untuk mengetahui lingkungan dan disiplin kerja yang memoderasi hubungan antara kompetensi pada kinerja auditor. MRA merupakan aplikasi khusus regresi linear untuk menentukan hubungan antara dua variabel yang dipengaruhi oleh variabel ketiga (variabel moderasi), dimana dalam persamaan regresinya mengandung unsur interaksi (Ghozali, 2016). Rumus uji MRA digambarkan dalam persamaan regresi sebagai berikut.

$\mathrm{KA}=\alpha+\beta_{1} \mathrm{X}_{1}+\beta_{2} \mathrm{X}_{2}+\beta_{3} \mathrm{X}_{3}+\beta_{4}\left(\mathrm{X}_{1} \mathrm{X}_{2}\right)+\beta 5\left(\mathrm{X}_{1} \mathrm{X}_{3}\right)+\varepsilon$.

Keterangan :

KA : Kinerja Auditor

$\alpha \quad$ : Konstanta

$\beta 1-\beta 5$ : Koefisien regresi masing-masing faktor

$\mathrm{X}_{1}$ : Pengaruh Kompetensi

$\mathrm{X}_{2}$ : Lingkungan Kerja

$\mathrm{X}_{3}$ : Disiplin Kerja

$\mathrm{X}_{1} \mathrm{X}_{2}$ : Interaksi Kompetensi dengan Lingkungan kerja

$\mathrm{X}_{1} \mathrm{X}_{3}$ : Interaksi Kompetensi dengan Disiplin Kerja

$\varepsilon \quad:$ Error 


\section{HASIL DAN PEMBAHASAN}

Responden dalam Penelitian ini adalah auditor yang bekerja pada kantor inspektorat Kota Denpasar di Bali yang memiliki tugas melakukan tinjauan terhadap pengendalian internal dan system akuntansi pemda (Pemerintah daerah), memeriksa dan menyempurnakan Laporan Keuangan. Pengumpulan data dilakukan melalui penyebaran kuesioner yang disebarkan langsung oleh peneliti kepada aparat Inspektorat Kota Denpasar. Namun tidak semua karyawan yang menjadi sampel penelitian mengembalikan seluruh kuesioner yang dikiriminkan. Jumlah kuesioner yang disebarkan kepada kantor Inspektorat Kota Denpasar ialah sebanyak 50 buah kuesioner. Penyebaran kuesioner hingga semua kuesioner tersebut terjawab dan terkumpul kembali pada peneliti menghabiskan waktu 10 hari yaitu mulai tanggal 23 Februari 2018 sampai tanggal 2 Maret 2018. Dari 50 buah kuesioner yang dibagikan terdapat 4 kuesioner yang hilang dan 6 kuesioner yang dikembalikan namun tidak diisi dengan lengkap sehingga kuesioner yang digunakan sebanyak 40 buah.

Berdasarkan 40 responden yang digunakan sebagai sampel, menunjukkan bahwa mayoritas penggunaan adalah dibagian Inspektur Pembantu Wilayah I sebanyak 15 orang atau sebesar 37,5\%, bagian Inspektur Pembantu Wilayah II sebesar 12 orang atau 30\%,Bagian Inspektur Pembantu Wilayah III sebesar 7 orang atau 17,5\% dan bagian keperawatan dan Bagian Inspektur Pembantu Wilayah IV sebesar 6 orang atau 15\%. Berdasarkan jenis kelamin dapat dilihat bahwa responden 
ISSN: 2302-8556

yang digunakan sebagai sampel menunjukkan bahwa mayoritas responden berjenis kelamin perempuan, yaitu sebanyak 27 orang atau sebesar 67,5\% dan sisanya sebanyak 13 orang atau sebesar 32,5\% adalah laki-laki. Berdasarkan jenjang Pendidikan mayoritas tingkat pendidikan pengguna sistem informasi adalah S1 yakni sebanyak 28 orang atau sebesar 70\%, D3 sebanyak 4 orang atau sebesar 1\%, dan S2 sebanyak 8 orang atau sebesar 29\%. Berdasarkan jabatan menunjukkan bahwa dari 40 responden yang digunakan sebagai sampel, sebagian besar memiliki jabatan senior auditor sebanyak 33 orang atau sebesar $82,5 \%$ dan yang memiliki jabatan junior auditor sebanyak 7 orang atau sebesar 17,5\%. Berdasarkan umur menunjukkan bahwa dari 40 responden yang digunakan sebagai sampel, sebagian besar berumur di $<30$ tahun sebanyak 3 orang atau sebesar 7,5\%, dilanjutkan yang berumur 30-45 tahun sebanyak 16 orang atau sebesar $40 \%$ dan yang berumur $40>$ sebanyak 21 orang atau sebesar 52,5\%. Berdasarkan pengalaman audit dapat dilihat bahwa responden yang digunakan sebagai sampel menunjukkan bahwa sebagian besar memiliki pengalaman audit dari 0-5 tahun sebanyak 2 orang atau sebesar 5\%, lalu dari 6-19 tahun sebanyak 25 orang atau sebesar $62,5 \%$ dan $10>$ tahun sebanyak 13 orang atau sebesar 32,5\%.

Statistik deskriptif disajikan untuk memberikan informasi mengenai karakteristik variabel-variabel penelitian yang terdiri dari jumlah amatan, nilai minimum, nilai rata-rata, dan standar deviasi (simpangan baku) dengan $\mathrm{N}$ merupakan banyaknya responden penelitian. Hasil analisis statistik deskriptif dapat dilihat pada Tabel 1. berikut. 
Tabel 1.

Hasil Statistik Deskriptif

\begin{tabular}{lccccc}
\hline \multicolumn{1}{c}{ Variabel } & N & Min. & Maks. & Rata-rata & $\begin{array}{c}\text { Standar } \\
\text { Deviasi }\end{array}$ \\
\hline Pengaruh Kompetensi $\left(\mathrm{X}_{1}\right)$ & 40 & 4.25 & 4.55 & 4.3725 & 3.457 \\
Lingkungan Kerja $\left(\mathrm{M}_{2}\right)$ & 40 & 3.4 & 4.3 & 3.833333 & 2.491 \\
Disiplin Kerja $\left(\mathrm{M}_{3}\right)$ & 40 & 3.575 & 4.225 & 4.075 & 6.294 \\
Kinerja Auditor (Y) & 40 & 4.225 & 4.425 & 4.391667 & 2.049 \\
\hline
\end{tabular}

Sumber: Data diolah, 2017

Tabel 1. menunjukkan bahwa variabel pengaruh kompetensi $\left(\mathrm{X}_{1}\right)$ memiliki nilai rata-rata sebesar 4.3725 dengan nilai minimum 4.25 dan nilai maksimum 4.55. Hal ini menunjukkan pengaruh kompetensi mampu mempengaruhi kinerja auditor dalam pemeriksaan audit pada Kantor Inspektorat Kota Denpasar karena dapat dilihat nilai rata-rata lebih mendekati nilai maksimal, yang artinya sebagian besar responden cenderung menjawab setuju pada 10 item pernyataan dalam variabel pengaruh kompetensi.

Pengujian data dalam penelitian ini menggunakan teknik analisis regresi analisis regresi moderasi MRA (Moderated Regression Analysis),yaitu mengetahui pengaruh Kompetensi Kerja, Lingkungan Kerja, Disiplin Kerja, Interaksi Kompetensi Kerja dengan Lingkungan Kerja, dan Interaksi Kompetensi Kerja dengan Disiplin Kerja terhadap Kinerja Auditor. Perhitungan koefisien regresi dilakukan dengan analisis regresi melalui software SPSS 18.0 for Windows, diperoleh hasil yang ditunjukan pada Tabel berikut: 
Tabel 2.

Hasil Analisis Regresi Moderasi MRA (Moderated Regression Analysis)

\begin{tabular}{|c|c|c|c|c|c|}
\hline & \multicolumn{2}{|c|}{$\begin{array}{l}\text { Unstandardized } \\
\text { Coefficients }\end{array}$} & \multicolumn{2}{|l|}{$\begin{array}{l}\text { Standardized } \\
\text { Coefficients }\end{array}$} & \multirow[t]{2}{*}{$\begin{array}{l}\text { Hasil Uj } \\
\text { Hipotesi }\end{array}$} \\
\hline & & $\begin{array}{l}\text { Std. } \\
\text { Error }\end{array}$ & Beta & Sig. & \\
\hline (Constant) & $3.618^{\mathrm{E}-15}$ & 0.100 & & 1.000 & \\
\hline Kompetensi $\left(\beta_{1}\right)$ & 0.275 & 0.130 & 0.275 & 0.042 & $\begin{array}{c}\mathrm{H}_{1} \\
\text { Diterima }\end{array}$ \\
\hline Lingkungan Kerja $\left(\beta_{2}\right)$ & 0.347 & 0.127 & 0.347 & 0.010 & \\
\hline Disiplin Kerja $\left(\beta_{3}\right)$ & 0.061 & 0.146 & 0.061 & 0.681 & \\
\hline Interaksi Kompetensi dengan & 0.247 & 0.119 & 0.247 & 0.046 & $\mathrm{H}_{2}$ \\
\hline Lingkungan Kerja $\left(\beta_{4}\right)$ & & & & & Diterima \\
\hline Interaksi Kompetensi dengan & 0.373 & 0.155 & 0.373 & 0.021 & $\mathrm{H}_{3}$ \\
\hline Disiplin Kerja $\left(\beta_{5}\right)$ & & & & & Diterima \\
\hline F Hitung & & & & & 12,719 \\
\hline Signifikansi & & & & & 0,000 \\
\hline RSquare & & & & & 0,652 \\
\hline Adjusted R Square & & & & & 0,600 \\
\hline
\end{tabular}

Sumber:Data diolah, 2018

Berdasarkan hasil analisis regresi moderasi seperti yang disajikan pada Tabel ,maka persamaan strukturalnya adalah sebagai berikut :

$$
\begin{array}{r}
\mathrm{Y}=\alpha+\beta 1 \mathrm{X}_{1}+\beta_{2} \mathrm{X}_{2}+\beta_{3} \mathrm{X}_{3}+\beta 4\left(\mathrm{X}_{1} \mathrm{X}_{2}\right)+\beta 5\left(\mathrm{X}_{1} \mathrm{X}_{3}\right)+\varepsilon \ldots . .(2) \\
\mathrm{Y}=3.618^{\mathrm{E}-15}+0,275 \mathrm{X} 1+0,347 \mathrm{M}_{1}+0,061 \mathrm{M}_{2}+0,247\left(\mathrm{X}_{1} \mathrm{M}_{1}\right)+0,373\left(\mathrm{X}_{1} \mathrm{M}_{2}\right)+\varepsilon
\end{array}
$$

Interpretasi dari persamaan diatas nilai konstanta $\alpha=3.618^{\mathrm{E}-15}$ memiliki arti apabila kompetensi, lingkungan, dan disiplin kerja konstan, maka nilai kinerja auditor (Y) sebesar3.618 ${ }^{\mathrm{E}-15}$ satuan.

Nilai koefisien $(\beta 1)$ sebesar 0.275 . Nilai koefisien positif menunjukan bahwa apabila kompetensi meningkat sebesar satu-satuan, maka kinerja auditor akan meningkat sebesar 0,275 dengan asumsi variabel bebas lainnya dianggap konstan. 
Nilai koefisien $(\beta 2)$ sebesar 0.347. Nilai koefisien positif hal ini menunjukan bahwa lingkungan kerja meningkatsebesar satu-satuan, maka kinerja auditor akan meningkat sebesar 0,347 dengan asumsi variabel bebas lainnya dianggap konstan.

Nilai koefisien $(\beta 3)$ sebesar 0,061 . Nilai koefisien positif hal ini menunjukan bahwa Disiplin kerja meningkat sebesar satu-satuan, maka kinerja auditor akan meningkat sebesar 0,061 dengan asumsi variabel bebas lainnya dianggap konstan.

Nilai koefisien $(\beta 4)$ interaksi antara kompetensi dengan lingkungan kerja sebesar 0,247. Nilai koefisien positif hal ini menunjukan interaksi kompetensi mampu memperkuat lingkungan kerja terhadap kinerja auditor pada kantor Inspektorat Kota Denpasar.

Nilai koefisien $(\beta 5)$ interaksi antara kompetensi dengan disiplin kerja sebesar 0,373. Nilai koefisien positif hal ini menunjukan interaksi kompetensi mampu memperkuat disiplin kerja terhadap kinerja auditor pada kantor Inspektorat Kota Denpasar.

Berdasarkan tabel 2. menunjukan bahwa Sig. Fhitung yang diperoleh adalah sebesar 0.000 yag lebih kecil dari $\alpha=0.05$, hal ini berarti model regresi telah memenuhi prasyarat kelayakan model regresi.

Berdasarkan hasil pengujian Tabel 2. menunjukan bahwa koefisien determinasi yaitu nilai adjusted $\mathrm{R}^{2}$ padaanalisis regresi moderasi menunjukan nilai sebesar 0.600 . Ini berarti sebesar $60 \%$ variabel kompetensi, lingkungan kerja dan disiplin kerja 
ISSN: 2302-8556

menjelaskan variasi dari kinerja auditor, sedangkan $40 \%$ sisanya dijelaskan oleh variabel lain diluar model.

Berdasarkan Tabel 2. maka hasil pengujian masing-masing variabel independen terhadap dependen dapat dijabarkan bahwa kompetensi terhadap kinerja auditor menunjukan tingkat signifikansi sebesar 0,042 $<0,050$ mengindikasikan bahwa $\mathrm{H}_{0}$ ditolak dan $\mathrm{H}_{1}$ diterima. Hasil penelitian ini menyatakanbahwaKompetensi berpengaruh positif dan signifikan terhadap Kinerja Auditor. Kompetensi sangat berperan penting dalam mendorong secara positif. Semakin tinggi kompetensi yang dimiliki oleh pegawai dan sesuai dengan tuntutan pekerjaan maka kinerja auditor akan semakin meningkat karena auditor yang berkompeten biasanya memiliki kemampuan dan kemauan yang cepat untuk mengatasi permasalahan kerja yang dihadapi.

Jawaban responden menunjukan bahwa tingkat rasa keingin tahuan yang besar, berpikir luas dan mampu menangani ketidak pastian cenderung tinggi, karena dengan adanya pengaruh positif yang signifikan antara kompetensi terhadap kinerja audit dapat memberikan pemahaman kepada auditor-auditor betapa pentingnya meningkatkan kompetensi untuk dapat meningkatkan kemampuan yang dimiliki untuk meningkatkan kualitas diri melalui proses pembelajaran (Pernyataan X.1). Secara psikologis hal ini dapat memberikan pengalaman kerja auditor yang bermakna dan rasa tanggung jawab mengenai hasil-hasil pekerjaan yang dilakukan, yang pada akhirnya semua ini akan meningkatkan kinerja auditor. Hasil penelitian ini selaras dengan penelitian yang dilakukan oleh Arina dkk (2012) dan sukriah dkk (2009) yang 
menyatakan bahwa semakin tinggi kompetensi auditor akan semakin baik kualitas hasil pemeriksaannya. Berbeda dengan penelitian Linawati dan Suhaji (2012) kompetensi tidak berpengaruh signfikan terhadap kinerja auditor. Begitu juga dengan Zamroni (2015) yang mengatakan bahwa tidak berpengaruh signifikan terhadap kinerja auditor.

Pengaruh interaksi antara variabel kompetensi dengan lingkungan kerja terhadap kinerja auditor menunjukan tingkat signifikansi sebesar0,046 $<0,050$ mengindikasikan bahwa $\mathrm{H}_{0}$ ditolak dan $\mathrm{H}_{1}$ diterima. Hasil penelitian ini menyatakan bahwavariabel lingkungan Kerja (M1) merupakan variabel moderasi yang memperkuat pengaruh Kompetensi Kerja pada Kinerja Auditor. Tujuan penelitian dari hipotesis kedua ini adalah untuk mengetahui lingkungan mampu mempengaruhi kompetensi dalam menyelesaikan pekerjaan serta dapat meningkatkan kinerja auditor. Jawaban responden menunjukan dengan seringnya melakukan pekerjaan rutin seperti mmeriksa audit dapat meningkatkan kompetensi auditor dalam lingkungan kerja yang baik dan mampu mempengaruhi kualitas kinerja auditor (Pernyataan M1.1). Hal ini dapat terjadi karena semakin baik lingkungan kerja seorang auditor dapat meningkatkan kompetensi dalam melaksanakan audit dan menghasilkan kinerja auditor yg baik.

Untuk mengetahui jenis moderasi dalam penelitian ini maka dapat dilihat pada tabel 2. yaitu hasil analisis regresi moderasi menunjukkan bahwa nilai koefisien regresi Lingkungan Kerja $\left(\beta_{2}\right)$ positif sebesar 0,347 dengan nilai signifikansi 0,010< 0,050 dan Interaksi Kompetensi dengan Lingkungan kerja ( $\left.\beta_{4}\right)$ positif sebesar 0,247 
ISSN: 2302-8556

dengan nilai signifikansi $0,046<0,05$. Hal ini mengindikasikan variabel moderasi merupakan tipe moderasi quasi (quasi moderasi). Quasi moderasi merupakan variabel yang memoderasi hubungan antara variabel prediktor yaitu moderasi berhubungan dengan variable indpenden, namun tidak berinteraksi dengan variable independen dan variabel tergantung di mana variabel moderasi quasi berinteraksi dengan variabel predictor sekaligus menjadi variabel prediktor. Oleh karena nilai koefisien regresi variabel kompetensi kerja dan variabel interaksi kompetensi dengan lingkungan kerja positif, maka dapat disimpulkan bahwa variabel lingkungan Kerja $\left(\mathrm{M}_{1}\right)$ merupakan variabel moderasi yang memperkuat pengaruh Kompetensi Kerjapada Kinerja Auditor.

Pengaruh interaksi antara variabel kompetensi dengan disiplin kerja terhadap kinerja auditor menunjukan tingkat signifikansi sebesar $0,021<0,050$ mengindikasikan bahwa $\mathrm{H}_{0}$ ditolak dan $\mathrm{H}_{2}$ diterima. Hasil penelitian ini menyatakan bahwa variabel Disiplin Kerja (M2) merupakan variabel moderasi yang memperkuat pengaruh Kompetensi Kerjapada Kinerja Auditor. Tujuan penelitian dari hipotesis ketiga ini adalah untuk mengetahui disiplin kerja mampu mempengaruhi kompetensi dalam menyelesaikan pekerjaan serta dapat meningkatkan kinerja auditor Meningkatnya kompetensi seorang auditor yang memiliki disiplin tinggi maka mampu membuat kinerja seorang auditor meningkat dan memiliki kualitas yang baik. Hal tersebut dikarenakan seorang auditor harus memiliki tanggung jawab dalam melaksanakan pekerjaannya sendiri sehingga dapat menyelesaikan perkerjaan sesuai dengan aturan yg berlaku (Pernyataan M2.10). 
Untuk mengetahui jenis moderasi dalam penelitian ini maka dapat dilihat tabel 4.13 yaitu hasilanalisis regresi moderasi menunjukkan bahwa nilai koefisien regresi Disiplin Kerja $\left(\beta_{3}\right)$ positif sebesar 0,061 dengan nilai signifikansi 0,681 > 0,05 dan $\beta_{5}$ positif sebesar 0,373 dengan nilai signifikansi $0,021<0,05$. Hal ini mengindikasikan variabel moderasi merupakan tipe moderasi murni. Pure moderasi atau moderasi murni merupakan variabel yang memoderasi hubungan antara variabel prediktor dan variabel tergantung di mana variabel moderasi murni berinteraksi dengan variabel prediktor tanpa menjadi variabel prediktor. Oleh karena nilai koefisien regresi variabel kompetensi kerja dan variabel interaksi kompetensi dengan disiplin kerja positif maka dapat disimpulkan bahwavariabel Disiplin Kerja $\left(\mathrm{M}_{2}\right)$ merupakan variabel moderasi yang memperkuat pengaruh Kompetensi Kerjapada Kinerja Auditor.

Penelitian ini menghasilkan bahwa pengaruh kompetensi berpengaruh signifikan pada kinerja auditor. Hal ini mendukung teori kontijensi yang menyebutkan mampu mengidentifikasi bentuk-bentuk optimal seperti kompetensi pada kinerja auditor dalam pengendalian organisasi di bawah kondisi operasi yang berbeda dan mencoba untuk menjelaskan bagaimana prosedur operasi pengendalian organisasi tersebut. Hasil uji dalam penelitian ini ditemukan bahwa kedua variabel moderasi yaitu lingkungan dan disiplin kerja mampu memoderasi pengaruh kompetensi terhadap kinerja auditor. Berdasarkan hasil statistik, kedua variable moderasi merupakan pure moderasi danquasi moderasi. Penelitian ini juga menghasilkan lingkungan dan disiplin kerja mampu memperkuat atau memperlemah pengaruh kompetensi pada 
ISSN: 2302-8556

kinerja auditor. Hal ini menunjukan bahwa pengaruh kompetensi yang tinggi dengan lingkungan dan disiplin kerja yang tinggi yang dirasakan auditor maka akan mempengaruhi kinerja auditor.

Hal ini juga mendukung teori disonasi kognitif dalam penelitian ini yaitu bagaimana pengaruh kompetensi auditor jika terjadi disonasi kognitif dalam dirinya ketika mendeteksi kecurangan. Ini berarti dengan lingkungan yang baik dan disiplin yang tinggi dalam lingkungan kinerja auditor maka kompetensi yang dimiliki seorang auditor akan meningkat dan akan menghasilkan seorang auditor dengan kualitas yang baik.

Hasil penelitian ini dapat digunakan sebagai kontribusi bagi auditor dalam meningkatkan pengaruh kompetensi secara obyektif yang kemungkinan akan terdapat permasalahan dalam mengumpulkan dan menilai bukti signifikan, maka dari itu diharapkan dapat diatasi melalui peningkatan pengetahuan auditor, pengalaman auditor, dan tidak cepat merasa puas terhadap apa yg dikerjakan. Selain itu, Kantor Inspektorat juga perlu ikut serta dalam meningkatkan pengalaman yang dimiliki oleh auditor dengan cara melakukan pelatihan, tambahan pengetahuan tekhnikal mengenai strategi pengauditan dan cara penilaian bukti audit secara objektif, serta memberikan tugas audit yang beragam lagi khususnya untuk junior auditor sehingga dapat meningkatkan kualitas kinerja auditor menjadi lebih baik agar dan bisa mengatur kurun waktu penyelesaian pemeriksaan audit sesuai dengan waktu yang sudah ditentukan. 


\section{SIMPULAN}

Berdasarkan pembahasan hasil penelitian yang telah diuraikan maka dapat disimpulkan bahwa Kompetensi berpengaruh positif signifikans pada kinerja auditor di Kantor Inspektorat Kota Denpasar. Semakin tinggi kompetensi seorang auditor, maka akan semakin meningkat kualitas kinerja auditor.

Lingkungan kerja mampu memoderasi pengaruh kompetensi pada kinerja auditor di Kantor Inspektorat Kota Denpasar. Semakin baik lingkunga kerja maka semakin baik juga kompetensi pada kinerja auditor.

Disiplin kerja mampu memoderasi mampu memoderasi pengaruh kompetensi pada kinerja auditor di Kantor Inspektorat Kota Denpasar. Semakin tinggi disiplin yang dimiliki seorang auditor maka semakin tinggi juga pengaruh kompetensi pada kinerja auditor.

Berdasarkan pembahasan hasil penelitian dan simpulan yang telah diuraikan maka saran yang dapat disampaikan adalah Bagi Kantor Inspektorat Kota Denpasar peneliti menyarankan kepada aparat Inspektorat untuk lebih meningkatkan kompetensi dengan cara memberikan pendidikan pelatihan secara berkala kepada auditor, lebih meninjau kembali waktu pengerjaan yang harus diselesaikan agar tepat waktu dan meningkatkan fasilitas-fasilitas sehingga dapat mendukung kinerja auditor agar kompetensi masing-masing auditor juga meningkat.

Perlu meningkatkan hubungan antar auditor dengan kegiatan bersama untuk mempererat hubungan yang lebih baik agar mampu mendukung kinerja auditor yang baik dan tepat. 
ISSN: 2302-8556

E-Jurnal Akuntansi Universitas Udayana

Vol.25.3.Desember (2018): 2041- 2071

Bagi peneliti selanjutnya dapat memperluas area penelitian, tidak hanya pada

Kantor Inspektorat Kota Denpasar saja tetapi dapat memperluas area penelitian di BPK/BPKP, menambah populasi penelitian seperti penambahan ruang lingkup geografis, responden maupun penambahan jumlah responden, dan menambahkan variabel independen lainnya.

\section{REFERENSI}

Agoes, Sukrisno. 2004. Auditing (Pemeriksaan Akuntan) oleh Kantor Akuntan Publik. Edisi Ketiga. Penerbit Fakultas Ekonomi Universitas Trisakti.

Ajibolade, S.O. and Akinniyi, O.K. 2013. The Influence of Organisational Culture and Budgetary Participation on Propensity to Create Budgetary Slack in Public Sector Organisations. British Journal of Arts and Social Scienes, 13(1), pp: 6983.

Amran. 2009. "Pengaruh Disiplin Kerja Terhadap Kinerja Pegawai kantor Departemen Sosial Kabupaten Gorontalo". Dalam Jurnal Ichsan Gorontalo, Volume 4 No. 2. Hal 2397-2413. Gorontalo: Universitas Ichsan Gorontalo.

Ardana, I Komang. Mujiati, Ni Komang. dan Utama, I Wayan Mudiartha. 2011. Manajemen Sumber Daya Manusia. Edisi Pertama: Graha Ilmu.

Ariani, Komang Gunayanti. 2015. Pengaruh Integritas, Obyektifitas, Kerahasiaan dan Kompetensi pada Kinerja Auditor Inspektorat Kota Denpasar. Jurna Akuntansi Universitas Udayana.

Arens, Alvin A \& Loebbecke, James K. 2011. Auditing, an Integrated Approach. Seventh Edition. Upper Saddle River,New Yersey: Prentice-Hall, Inc.

Ariyanto, Dodik dan Ardani Mutia Jati. 2010. Pengaruh Independensi, Kompetensi, dan Sensitivitas Etika Profesi Terhadap Produktivitas Kerja Auditor Eksternal (Studi Kasus Pada Auditor Perwakilan BPK RI Provinsi Bali). Jurnal Akuntansi dan Bisnis 5 (2): h:157-168.

Azza, S.M. Gaballa, dan Zhou, Ning. 2010. An Analytic study of the effects of experience on the performance of the external Auditor. International Journal Conference on Bussiness and Economics Research. 1(3): h169-173 
Bedard, Jean et al. 1993. Epertise in Auditing Journal of Pratice. 12 (21)

Bing, J., Chu, X, H., Anqi, L., Xinyi, Z. 2014. A Report Prepared by the 2013-14 Summer Interns in the Research School of Accounting and Business Information Systems. Audit Quality research Report. Australian National Centre for Audit and Assurance Research Hanna Neumann Building \#21 Canberra ACT 0200 Australia.

Brown, P.A, H. Stock Morris, and Wark Wilder. 2007. Ethical Exemplication and The AICPA Code Profesional Coduct: And Empirical Investigation of Auditor \& Public Perception. Journal Of Business Ethis 71:h:39-71

Boynton, W.C., Johnson, R.N., \& Kell, W.G., 2006, Modern Auditing, 8th Edition, USA Richard D. Irwin Inc.

Dermawan, A.A. Ngurah Bagus, Sudibya, I Gede Adanyana, dan Utama, I Wayan Mudiartha. 2011. Pengaruh Motivasi, Lingkungan Kerja, Kompetensi, dan Kompensasi terhadap Kepuasan Kerja dan Kinerja Pegawai di Lingkungan Kantor Dinas Pekerjaan Umum Provinsi Bali.

Engko, Cecilia. 2006. Pengaruh Kepuasan Kerja terhadap Kinerja Individual dengan Self Esteem dan Self Efficacy sebagai Variabel Intervening. Simposium Nasional Akuntansi IX. 23-26 Agustus, Padang.

Felix, Eluyela Damiola., and Osiregbemhe, Ilogho Simon. 2016. Audit Standards and Performance of Auditors :Evidence from Nigerian Banking Industry. Journal International Conference on African Development Issues. 3(1): h: 241244.

Gavious, Ilanit. 2007. Alternative Perspective to Deal With Auditor's Agency Problem. Critical Perspective On Accounting, 18,pp: 451-467

Halim, Abdul. 2015. Auditing. Edisi Kelima. Jakarta:Salemba Empat.h:1-50

Handoko T, Hani. 2006. Manajemen personalia dan Sumber Daya Manusia. Edisi 2, Yogyakarta: BPFE UGM

Hasibuan, Malayu. 2007. Manajemen Sumber Daya Manusia. Jakarta: PT Bumi Aksara. 
ISSN: 2302-8556

E-Jurnal Akuntansi Universitas Udayana

Vol.25.3.Desember (2018): 2041- 2071

Husam Al-Khaddash, Rana Al Nawas and Abdulhadi Ramadan. 2013. Factors affecting the quality of Auditing: The Case of Jordanian Commercial Banks. International Journal of Business and Social Science. 4(11): h:206-222

Iskandar. 2017. Pengaruh Karakteristik Individu, Beban Kerja dan Lingkungan Terhadap Kinerja Pegawai Pada Kantor Inspektorat Daerah Provinsi Sulawesi Tengah. Jurnal Akuntansi.

Kane, G., dan Velury, U. 2005. The Impact Managerial Ownship on The likelihood of Provision of High Quality Auditing Service. Review of Accounting \& Finance.

Kalbers, Lawrance P. dan Timothy J. Forgaty. 1995. Profesionalism its Consequences : A Study of Internal Auditor Auditinng : Journal of Pratice Vol. 14 No 1: 64-86

Linawati, Suhaji. 2012. Perilaku Keorganisasian. Edisi Kedua. Yogykarta: Universitas Atma Jaya

Listya Yuniastuti Rahmania, Sukrisno Agoes. 2014. Influence of Auditor, Independence, Audit tenure and Audit Fee on Audit Quality Members of Capital Market Accountant forum in Indonesia. International Journal and Behavioral Sciences. 16(1): h: 324-331

Mangkunegara, A.A. Anwar Prabu. 2006. Evaluasi Kinerja SUmber Daya Manusia. Edisi Pertama. Manusia Perusahaan. Bandung: PT. Salemba Emban Patria.

Meylinda Triyanthi dan Budiartha, Ketut. 2015. Pengaruh Profesionalisme, Etika Profesi, Independensi dan Motivasi Kerja pada Kinerja Internal Auditor (Studi Kasus Pada Dealer Yamaha di Kota Denpasar). Jurnal Akuntansi Universitas Udayana 10(3):h: 797-809

Mulyadi. (2002). Auditing Edisi Kelima. Jakarta: Salemba Empat.

Nila, Gustia. 2014. Pengaruh Independensi Auditor, Etika Profesi, Komitmen Organisasi dan Gaya Kepemimpinan Terhadap Kinerja Pemerintah (Studi Empiris Pada Auditor Pemerintah di BPKP Perwakilan Sumba). Jurnal Akuntansi. 1(5): h: 15-23

Pamungkas, Bambang. 2012. Pengaruh Penerapan Akuntansi Sektor Publik dan Pengawasan terhadap Kualitas Laporan Keuangan dan Implikasinya terhadap 
Akuntabilitas Kinerja Instansi Pemerintah. Jurnal Ilmiah Ranggagading. Vol. 12 No. 2: 82-93.

Praditaningrum, Anugrah Suci 2012. Analisis Faktor-Faktor Yang Berpengaruh Terhadap Audit Judgement. Tesis. Fakultas Ekonomi dan Bisnis Universitas Diponegoro

Riris Rotua Sitorus dan Lenny Wijaya. 2016. Pengaruh Profesionalisme dan Etika Profesi Terhadap Kinerja Auditor dengan Struktur Audit sebagai Pemoderasi. Jurnal Media Studio Ekonomi. 19(2): h: 98-11

Rita Anugrah Ria Nelly Sari Rina Mona Frostiana. 2011. The Relationship Between Ethics, Expertise, Audit Experince, Fraud Risk Assesment and Audit Situational Factors on Auditor Professional Skepticism. Jurnal Repository Akuntansi. 1(1): h: 1-21.

Satwika Adhi Nugraha, Ida Bagus., dan Ramantha, I Wayan. 2015. Pengaruh Profesinalisme, Etika Profesi dan Pelatihan Auditor terhadap Kinerja Auditor pada Kantor Akuntan Publik di Bali. Jurnal Akuntansi Universitas Udayana.

Supriyatno, dan Sukir. 2007. Pengaruh Disiplin Kerja, Lingkungan Kerja dan Motivasi Kerja Terhadap Kinerja Karyawan. Jurna Manajemen Sumber Daya Manusia, Volume 2 No.1. Hal 23-34. Karanganyar: Universitas Slamet Riyadi Surakarta.

Tubbs, R. M. 1998. The Effect Of Experience On The Auditor's Organization and Amount Of Knowledge The Accounting Review. 57(4): pp 783-801.

Watts, Ross L and Zimmerman, Jerold J. 1983. Agency Problem, Auditing and Theory of The Firm, Some Evidence. Journal of Law and Economics, October.

Wijayanthi, P.K. dan Widanaputra, A.A.G.P. 2016. Pengaruh Partisipasi Penganggaran pada Senjangan Anggaran Dengan Kepercayaan Diri dan Ketidakpastian Lingkungan sebagai Pemoderasi. E-Jurnal Akuntansi Universitas Udayana, 15(1), h: 695-726.

Wicaksana, Made dan Budiartha, Ketut. 2015. Tingkat Pendidikan, Pengalaman Kerja, Komitmen Profesional, dan Disiplin Kerja Pada Rentang Waktu Penyelesaian Audit. Jurnal Akuntansi Universitas Udayana. 
ISSN: 2302-8556

E-Jurnal Akuntansi Universitas Udayana

Vol.25.3.Desember (2018): 2041- 2071

Yadnya. I Putu Parta. 2017. Pengaruh Kompetensi dan Independensi pada Kinerja Auditor dengan Etika Auditor SEbagai Variabel Moderasi. E-Jurnal Akuntansi Universitas Udayana.

Zamroni. (2015). Analisis Pengaruh Kompetensi, Pengalaman danIndependensi Terhadap Kualitas Audit pada Direktorat Audit DJBC.Skripsi. Jakarta, Indonesia: STAN.

Zesbendri, dan Ariyanti. 2005. "Pengaruh Disiplin Kerja Terhadap Kinerja Pegawai pada Kantor Badan Pusat Statistik Kabupaten Bogor". Bogor: STIE IPWIJA. 